\title{
DETERMINATION OF HONEY GEOGRAPHIC ORIGIN ACCORDING TO ITS ELEMENTAL COMPOSITION BY THE METHOD OF X-RAY FLUORESCENCE
}

\author{
Victoria Kasianchuk \\ Department of Public Health \\ Medical Institute of Sumy State University \\ 31 Sanatorna str., Sumy, Ukraine, 40018 \\ v.kasyanchuk@med.sumdu.edu.ua \\ Oleksanda Berhilevych \\ Department of Public Health \\ Medical Institute of Sumy State University \\ 31 Sanatorna str., Sumy, Ukraine, 40018 \\ o.bergylevych@med.sumdu.edu.ua

\section{Inna Negai} \\ Odessa Regional State Laboratory of the Civil Service of Ukraine on the quality of food safety \\ and consumers' protection \\ 27 Mayatskaya Road str., Chlibodarsk, Odessa region, Ukraine, 67667 \\ in_ledi_gaga@mail.ru

\section{Lubov Dimitrijevich} \\ Department of of food technology \\ Sumy National Agrarian University \\ 160 Herasyma Kondratieva str., Sumy, Ukraine, 40021 \\ dimitriiech@ukr.net \\ Tatyana Marenkova \\ Department of of food technology \\ Sumy National Agrarian University \\ 160 Herasyma Kondratieva str., Sumy, Ukraine, 40021 \\ tanya_201@ukr.net
}

\footnotetext{
Abstract

The aim of the research was to determine features of the elemental composition of polyfloral honey from the Odessa region (Ukraine) by the method of $\mathrm{x}$-ray fluorescence for using these features in the geographic marking of the region of honey origin. A choice of honey from the Odessa region is explained by its relatively good ecology, optimal maritime climate and enough motley grass resources for gathering nectar by bees. At the same time the Odessa region occupies the fourth place among regions - honey producers in Ukraine with a right to export honey beyond the country with specific weight $10 \%$ from the total export of this product.

11 samples of fresh honey and 14 samples of honey, stored during one year were studied as to the content of 22 mineral elements. The elemental analysis of honey was realized on the energy-dispersive x-ray fluorescent spectrometer ElvaX Light SDD. Each sample was studied for 5 times. The obtained results were statistically processed by the standard methodology. The determination distinctness of mass shares of metals is no worse than $0,1 \%$. Limits of finding admixtures of heavy metals in the light matrix are no worse than $1 \mathrm{ppm}$. The studies were realized during 2016-2017.

It has been established, that lyophilization of honey doesn't essentially influence determination parameters of the elemental composition of honey by the method of x-ray fluorescence. The analysis of energy-dispersive spectrums of mineral elements determined that marker elements for honey from the Odessa region are $\mathrm{Cl}, \mathrm{K}, \mathrm{Ca}$, that prevail among other studied mineral elements. There has been established the typical intensity of a signal of energy-dispersive spectrums for $\mathrm{Cl}, \mathrm{K}, \mathrm{Ca}$ of honey from the Odessa region that correspond to the following values: for fresh honey $\mathrm{Cl}$ from 27075 to 29429; $\mathrm{K}$ from 47296 to 41 546; Ca from 7572 to 6928; for honey, stored during one year: $\mathrm{Cl}$ from 40383 to 37044; $\mathrm{K}$ from 43589 to 42 591; Ca from 15495 to 10006. These parameters
} 
may serve as markers for honey from the Odessa region. At the same time the obtained results may be used for controlling the quality of natural honey by its element composition for identifying a geographic place of origin.

Keywords: polyfloral honey, elemental analysis, energy-dispersion, X-ray fluorescent spectrometer, Cl, K, Ca.

\section{Introduction}

Bee honey is a product with unique food and healing properties, so its consumption in the world continuously grows. At the same time honey production is one of the most important branches of agriculture of the USA, some EU countries, Africa, Asia and Ukraine [1]. This natural product is very popular among persons of elder age and among children because of its consumption properties. It is well-known, that due to the essential amount of mineral substances, vitamins, simple sugars, organic acids, antioxidants and enzymes, honey is considered as a good product with nutritive, healing and cosmetic properties [2].

Different types of honey contain near 300 diverse components, 100 of them are always present in each type. Main components of honey are carbohydrates, water, proteins, free amino acids, enzymes, vitamins, mineral substances. It is commonly known, that the honey composition is influenced by the region, where it was produced. That is why honey from certain regions may have better properties, comparing with other honey types, so higher demand and price [3-5].

The resolution of the European Parliament presents a list of products, subjected to the highest risk of fraud in the food sphere [6]. Honey is included in this list. One of fraud types is declaration of the botanical or geographic origin of it. European consumers worry about a possibility of falsification, especially if talk about more expensive types of honey. At producing honey with indicating a place of its origin, there may take place its falsification by mixing it with one from different regions [7, 8].

Beekeepers of many countries have patented specific markers of honey that allow to determine its origin place and to confirm its specific signs. It allows to honey protect from a certain place from such falsifications as mixing with other honey types [9].

A traditional determination of geographic and/or botanical origin of honey is a study of pollen of bee plants [10]. But this method is rather laborious and insufficiently reliable, especially for polyfloral honey, because pollen of bee plants may be added in honey artificially. In this connection scientists offer different marker combinations for identifying a geographic origin of honey: content of carbohydrates, proteins, furfural hydroxyl oxymethyl, and also definitions of the complex of physical and chemical quality parameters of honey $[10,11]$.

Most scientists think that the mineral content of honey may be a marker sign of its origin that is confirmed by the following data of scientific publications. Mineral substances of honey are presented by 37 macro- and microelements that have importance for its food value. The ratio of correspondent elements in honey depends on soil, where bee plants grow and from the environment. The content of mineral substances in honey varies from 0,006 to 3,45\%. Light floral honey types contain near $0,2-0,3 \%$ of these elements, dark floral from 0,5 to $0,6 \%$. Honey includes 13 elements, most spread in the earth's crust (B, Si, $\mathrm{Al}, \mathrm{Fe}, \mathrm{Cu}, \mathrm{Na}, \mathrm{K}, \mathrm{Mg}, \mathrm{H}, \mathrm{Ca}, \mathrm{P}, \mathrm{S}, \mathrm{Mn})$. It is universally recognized, that all honey types contain calcium, magnesium, manganese, phosphorus, silicon, cooper and nickel. Especially much K, P, Ca are in honey. At the same time Tl, Ag, As, Ba, Bi, Cd, Co, Cr, Ge, Hg, Ni, $\mathrm{Pd}, \mathrm{Sb}, \mathrm{Sn}, \mathrm{V}, \mathrm{Zn}, \mathrm{W}$ were found in honey from different countries [10-13].

Chinese researchers determined using mass-spectrometry with the inductively-connected plasma (ICP-MS) that most spread minerals in honey from different regions of China are $\mathrm{K}, \mathrm{Ca}, \mathrm{Na}$ and $\mathrm{Mg}$. So they state that the mineral composition of honey depends on its region of origin [10]. The same method revealed that most spread macroelements in honey from the Southern and Eastern districts of Turkey were $\mathrm{K}, \mathrm{Na}$ and $\mathrm{Ca}$, and most spread microelements - $\mathrm{Zn}$ and $\mathrm{Cu}$ [13]. Using another method (spectral x-ray fluorescent spectroscopy), it was determined, that $\mathrm{K}$ and $\mathrm{Ca}$ are observed most often in honey samples from four regions of the Rio-de-Janeiro state (Brazil) [11]. 
The study of scientists from different countries demonstrated that the quality and quantity ratio of mineral substance differs in honey of different regions that may be a reliable marker of the geographic origin of honey.

The problem of Ukraine is that honey is exported in big parties, but packed and marked in Europe, so it is written on a label not "Ukrainian honey", but "honey, produced in EU countries". Consumers are ready to pay more for specific attractive features of honey, signed on a mark, for example, indication of an origin place that is ecologically safe. At the process of marking honey, its name may be added by information about its origin place. Ukrainian honey may have indications of a place of geographic origin on a mark, for example "Ukrainian honey" or an origin region "Odessa honey", if producers confirm its specific markers and methods of their identification. But unfortunately there is no such marking for Ukrainian honey for today. It is connected with a fact that honey is a multi-component product, and it is difficult to determine specific features of its composition, inherent to a certain location.

There are no studies in Ukraine about regional peculiarities of the content of micro- and macroelements and their ratio in honey as marker parameters for determining its geographic origin that is an important marketing factor for determining its consumption price, including one at the world market. The topicality of the research theme is determined also by the fact that together with a function of individualization of unique honey as a commodity, produced at the territory of a certain geographic object, geographic marking of an origin place plays an important role of legal protection of its unique properties and also informs a consumer about their uniqueness.

The aim of this research was to determine peculiarities in the elemental composition of natural polyfloral bee honey from the Odessa region (Ukraine) that differs from honey from other regions. The method of x-ray fluorescence was used for it. Fixed features of the elemental composition of Odessa honey may be used for identifying this region of honey origin at international trade.

\section{Materials and methods}

Samples of polyfloral honey from the Odessa region (Ukraine) were used in the study for determining its elemental composition by the method of x-ray fluorescence. This method advantageously differs by its speed and distinctness comparing with other ones, and at the same time it allows to obtain results by most chemical elements. The elemental analysis of honey was realized on the energy-dispersive x-ray fluorescent spectrometer ElvaX Light SDD (LTD ,ELVATECH”, Ukraine).

There were studied 11 samples of fresh honey and 14 ones of honey, stored during one year. This storage term was chosen, because it is universally recognized, that honey keeps its properties during a year at optimal storage conditions, and after year some of them may worsen, for example, organoleptic, bactericidal ones and enzyme composition. The Odessa region was chosen for the study, because this region of Ukraine with a little number of industrial enterprises - polluters of the external environment, and most its territory is occupied by resort zones. The region has a warm, soft, maritime climate and many territories with gardens of fruit trees and meadows with motley grass that are valuable resources of bee plants. For example, according to the ecological rating of Ukrainian regions, made by the Ukrainian organization "Green fund", emissions of polluting substances in the atmosphere in 2017 in the Odessa region were $0,9 \mathrm{t} / \mathrm{km}^{2}$, whereas in such regions as Kharkiv - 1,4 t/ $\mathrm{km}^{2}$, Lugansk $-2,8 \mathrm{t} / \mathrm{km}^{2}$, Cherkasy $-2,3 \mathrm{t} / \mathrm{km}^{2}$, Lviv $-5,0 \mathrm{t} / \mathrm{km}^{2}$ [14]. In the Odessa region there are many cultured and wild plants that provide honey, unique by its taste qualities. The most popular honey sort of this region is meadow one, gathered by bees from motley grass. The Odessa region occupies the fourth place among regions - honey producers in Ukraine with a right to export honey beyond the country with specific weight $10 \%$ from the total export of this product.

\section{1. Experimental procedures}

At first there was carried out the comparative study of the elemental composition of honey from the Odessa region by x-ray fluorescent spectrometer in native (natural polyfloral honey) and lyophilized samples after their sublimation. Honey samples were placed on the support of the en- 
ergy-dispersive x-ray fluorescent spectrometer. The elemental composition of "light" elements and "heavy" ones was determined according to the regimes, cited below.

The studies were conducted as follows: a batch of a honey sample with mass $10 \mathrm{~g}$ was studied using the energy-dispersive x-ray fluorescent spectrometer with an x-ray tube and rhodium anode. At studying the first group of "light" elements (from $\mathrm{Na}$ to $\mathrm{Sc}$ ), the tension on the tube was $10 \mathrm{~kW}$ without a filter of primary x-ray radiation. For the analysis of the group of "heavy" elements (from Ti) there was used the tension of the x-ray tube as $40 \mathrm{~kW}$ and the aluminium filter of primary $\mathrm{X}$-ray radiation with width $800 \mathrm{mcm}$. The current force was chosen automatically for achieving load level $50000 \mathrm{impulses} / \mathrm{s}$. Each sample was studied 5 times. The obtained results were statistically processed using Satistica software (version 8) for determining parametric indicators, namely determining mean values (M) and error of mean (m) [15]. The determination distinctness of mass shares of metals is no worse than $0,1 \%$. Limits of finding admixtures of heavy metals in the light matrix are no worse than $1 \mathrm{ppm}$.

\section{Results}

The obtained results are presented in Table 1. The data of Table 1 demonstrate that lyophilization almost didn't influence the intensity of a signal from the chemical elements of the sample. It has been also established, that the most intensity of a signal in the energy-dispersive spectrum of the elemental composition of honey was in such elements as $\mathrm{Cl}, \mathrm{K}, \mathrm{Ca}$.

Table 1

Elemental composition of honey samples of the Odessa region before and after lyophil drying

\begin{tabular}{|c|c|c|c|c|}
\hline \multirow{2}{*}{ No. by order } & \multirow{2}{*}{$\begin{array}{l}\text { Atom number of } \\
\text { element }\end{array}$} & \multirow{2}{*}{ Element } & \multicolumn{2}{|c|}{ Signal intensity } \\
\hline & & & Before sublimation & After sublimation \\
\hline 1 & 12 & $\mathrm{Mg}$ & $1087 \pm 11$ & $641 \pm 6$ \\
\hline 2 & 13 & $\mathrm{Al}$ & $1054 \pm 12$ & $982 \pm 8$ \\
\hline 3 & 14 & $\mathrm{Si}$ & $1773 \pm 9$ & $2722 \pm 13$ \\
\hline 4 & 15 & $\mathrm{P}$ & $2648 \pm 7$ & $4740 \pm 17$ \\
\hline 5 & 17 & Cl & $77568 \pm 21$ & $82409 \pm 21$ \\
\hline 6 & 19 & $\mathbf{K}$ & $76392 \pm 14$ & $75472 \pm 14$ \\
\hline 7 & 20 & $\mathrm{Ca}$ & $30505 \pm 11$ & $41335 \pm 11$ \\
\hline 8 & 23 & $\mathrm{~V}$ & - & $140 \pm 8$ \\
\hline 9 & 24 & $\mathrm{Cr}$ & $1631 \pm 13$ & $1590 \pm 13$ \\
\hline 10 & 25 & $\mathrm{Mn}$ & $363 \pm 5$ & $473 \pm 5$ \\
\hline 11 & 26 & $\mathrm{Fe}$ & $10498 \pm 15$ & $11048 \pm 13$ \\
\hline 12 & 27 & $\mathrm{Co}$ & $412 \pm 7$ & $511 \pm 11$ \\
\hline 13 & 28 & $\mathrm{Ni}$ & $6125 \pm 18$ & $6370 \pm 10$ \\
\hline 14 & 29 & $\mathrm{Cu}$ & $2428 \pm 12$ & $2817 \pm 9$ \\
\hline 15 & 30 & $\mathrm{Zn}$ & $2859 \pm 13$ & $1183 \pm 17$ \\
\hline 16 & 35 & $\mathrm{Br}$ & $1681 \pm 11$ & $1367 \pm 11$ \\
\hline 17 & 37 & $\mathrm{Rb}$ & $1838 \pm 14$ & $1918 \pm 14$ \\
\hline 18 & 38 & $\mathrm{Sr}$ & - & $2514 \pm 12$ \\
\hline 19 & 39 & $\mathrm{Y}$ & $2139 \pm 17$ & $3066 \pm 9$ \\
\hline 20 & 48 & $\mathrm{Cd}$ & $1111 \pm 15$ & $1202 \pm 8$ \\
\hline 21 & 50 & $\mathrm{Sn}$ & $1646 \pm 11$ & $1191 \pm 9$ \\
\hline 22 & 51 & $\mathrm{Sb}$ & $1293 \pm 8$ & - \\
\hline
\end{tabular}


The results of the study of polyfloral honey samples, stored during 1 year, are presented below (Table 2).

Table 2

Elemental composition of 14 samples of polyfloral honey from the Odessa region, produced in 2016 (after storage during 1 year)

\begin{tabular}{|c|c|c|c|c|c|c|c|c|c|c|c|c|c|c|}
\hline \multirow{3}{*}{ Elements } & \multicolumn{14}{|c|}{ Samples } \\
\hline & 1 & 2 & 3 & 4 & 5 & 6 & 7 & 8 & 9 & 10 & 11 & 12 & 13 & 14 \\
\hline & \multicolumn{14}{|c|}{ Signal intensity } \\
\hline $\mathrm{Mg}$ & & 235 & & & 623 & 460 & 391 & & & 260 & 234 & 383 & 350 & 224 \\
\hline Al & 559 & 441 & 391 & 312 & 634 & 474 & 570 & 360 & 365 & 490 & 388 & 632 & 482 & 350 \\
\hline $\mathbf{S i}$ & 956 & 600 & 516 & 1554 & 625 & 342 & 649 & 1054 & 414 & 1044 & 512 & 906 & 540 & 363 \\
\hline $\mathrm{P}$ & 1138 & 1527 & 1500 & 1336 & 1325 & 1284 & 1535 & 1115 & & 1863 & 1040 & 1714 & 1433 & 995 \\
\hline $\mathbf{C l}$ & 41505 & 46665 & 42285 & 32124 & 43218 & 35316 & 39930 & 38764 & 39375 & 48218 & 43290 & 47185 & 41413 & 25869 \\
\hline $\mathrm{K}$ & 35995 & 54696 & 52396 & 42029 & 48304 & 31599 & 36556 & 39266 & 50328 & 49241 & 37460 & 55895 & 47189 & 29287 \\
\hline $\mathrm{Ca}$ & 17458 & 15853 & 18102 & 11044 & 14746 & 11821 & 12911 & 18646 & 26543 & 20477 & 13212 & 17602 & 17153 & 1366 \\
\hline $\mathrm{V}$ & 136 & 155 & - & - & - & - & 113 & - & - & - & 106 & - & - & - \\
\hline $\mathrm{Cr}$ & 639 & 814 & 542 & 728 & 719 & 418 & 381 & 467 & 622 & 484 & 436 & 564 & 675 & 394 \\
\hline $\mathrm{Mn}$ & 194 & 273 & 305 & 354 & 228 & 144 & - & - & 158 & - & - & 317 & - & 159 \\
\hline $\mathrm{Fe}$ & 3554 & 5049 & 2953 & 4597 & 4446 & 2825 & 2926 & 2604 & 4016 & 2882 & 2917 & 3589 & 4120 & 2871 \\
\hline $\mathrm{Co}$ & 260 & 199 & - & 314 & 304 & 77 & - & - & 181 & 106 & 178 & 74 & - & 166 \\
\hline $\mathbf{N i}$ & 2392 & 2984 & 2254 & 2398 & 2380 & 1810 & 2112 & 2076 & 2497 & 1907 & 1991 & 2038 & 2321 & 2086 \\
\hline $\mathrm{Cu}$ & 837 & - & 715 & - & 997 & 703 & 726 & 681 & 970 & 642 & 582 & 861 & 1140 & 600 \\
\hline $\mathrm{Zn}$ & - & 356 & 436 & 389 & - & 212 & 466 & 257 & 610 & 267 & 266 & - & 305 & - \\
\hline $\mathrm{Ge}$ & - & - & 421 & - & - & - & - & - & - & - & - & - & - & - \\
\hline As & - & - & - & 703 & - & - & 557 & - & - & - & - & - & - & - \\
\hline $\mathrm{Se}$ & - & - & - & - & - & - & - & - & 815 & - & - & - & - & - \\
\hline $\mathrm{Br}$ & 899 & 677 & - & - & 1671 & 763 & 1082 & - & 485 & - & 1355 & - & 1078 & - \\
\hline $\mathrm{Rb}$ & - & 1483 & - & - & 513 & - & 943 & 839 & 2104 & - & 784 & - & 1442 & - \\
\hline $\mathrm{Sr}$ & - & - & - & - & - & - & - & - & 846 & - & 946 & - & - & 808 \\
\hline $\mathrm{Y}$ & - & 1137 & - & 1086 & 1264 & - & 1084 & 1180 & 545 & & 1338 & 920 & 612 & 1235 \\
\hline $\mathrm{Cd}$ & - & - & 474 & - & 347 & - & - & 641 & - & - & 1061 & 583 & - & - \\
\hline $\mathrm{Sn}$ & - & - & 864 & - & - & - & - & - & - & 970 & 1011 & - & 1135 & - \\
\hline $\mathrm{Sb}$ & - & - & - & - & - & - & - & 969 & - & - & - & 1095 & 982 & 1455 \\
\hline I & - & 1588 & 1475 & - & 815 & 622 & - & - & 1309 & 1673 & - & 744 & - & - \\
\hline $\mathrm{Ba}$ & - & - & 2218 & - & - & - & - & - & - & - & - & - & - & - \\
\hline $\mathrm{Hg}$ & - & - & - & - & - & - & - & - & 748 & - & - & - & - & - \\
\hline
\end{tabular}

Table 2 presents the intensity of a signal of elements, found in the honey samples, selected in 2016 and studied after storage during 1 year.

28 elements were found in the studied samples. 8 elements of 28 constantly were present in all honey samples: $\mathrm{Al}, \mathrm{Si}, \mathrm{Cl}, \mathrm{K}, \mathrm{Ca}, \mathrm{Cr}, \mathrm{Fe}, \mathrm{Ni}$.

At that the most signal intensity was typical for such elements as $\mathrm{Cl}, \mathrm{K}, \mathrm{Ca}$. The rest of elements occurred in not all honey samples, but most often the following: $\mathrm{P}$ (13 samples); $\mathrm{Cu}$ (12 samples); Zn, Y (10 samples) Mn (9 samples), Br (8 samples), the other elements were present in the insufficient number of samples. The data of table 2 also testify that the elements $\mathrm{Cl}, \mathrm{K}, \mathrm{Ca}$ are 
constantly present in honey of the Odessa region and generate strongest signal of x-ray radiation comparing with the other elements.

Then samples of fresh polyfloral honey were studied using the energy-dispersive $\mathrm{x}$-ray fluorescent spectrometer as it was described above. The research results are presented in Table 3.

Table 3

Elemental composition of 11 sample of fresh polyfloral honey from the Odessa region, produced in 2017

\begin{tabular}{|c|c|c|c|c|c|c|c|c|c|c|c|}
\hline \multirow{3}{*}{ Elements } & \multicolumn{11}{|c|}{ Samples } \\
\hline & 1 & 2 & 3 & 4 & 5 & 6 & 7 & 8 & 9 & 10 & 11 \\
\hline & \multicolumn{11}{|c|}{ Signal intensity } \\
\hline $\mathrm{Mg}$ & 179 & 226 & 237 & - & 301 & 104 & 440 & 224 & 9 & - & 122 \\
\hline Al & 479 & 582 & 347 & 519 & 437 & 408 & 422 & 481 & 508 & 497 & 544 \\
\hline $\mathrm{Si}$ & 455 & 527 & 418 & 572 & 544 & 467 & 228 & 370 & 497 & 458 & 349 \\
\hline $\mathrm{P}$ & 1184 & - & 1024 & - & 979 & 855 & 930 & 1508 & - & 1393 & 915 \\
\hline Cl & 23952 & 37274 & 26092 & 31224 & 25038 & 37860 & 23398 & 37049 & 38135 & 16014 & 27685 \\
\hline $\mathrm{K}$ & 26189 & 76037 & 28857 & 51351 & 25999 & 32186 & 18554 & 45529 & 73060 & 23513 & 55727 \\
\hline $\mathrm{Ca}$ & 4470 & 10752 & 4191 & 6089 & 2753 & 12390 & 3823 & 9030 & 12419 & 4075 & 6215 \\
\hline $\mathrm{V}$ & 151 & - & - & - & - & - & - & - & - & - & 89 \\
\hline $\mathrm{Cr}$ & 514 & 610 & 696 & 824 & 462 & 729 & 585 & 421 & 542 & 558 & 708 \\
\hline $\mathrm{Mn}$ & 197 & - & - & - & 129 & - & 189 & 294 & 211 & 303 & 139 \\
\hline $\mathrm{Fe}$ & 3839 & 4011 & 4255 & 5019 & 2976 & 4396 & 3524 & 3292 & 3699 & 3359 & 4261 \\
\hline $\mathrm{Co}$ & 103 & 243 & 161 & 313 & - & 99 & 141 & 169 & 375 & 193 & 145 \\
\hline $\mathrm{Ni}$ & - & 2146 & 2474 & - & 2147 & 2255 & 1830 & 2269 & 2608 & 2237 & 2413 \\
\hline $\mathrm{Cu}$ & 755 & 1027 & 1149 & 1103 & 801 & 950 & 832 & 753 & 987 & 807 & 915 \\
\hline $\mathrm{Zn}$ & 10718 & 2285 & 486 & 885 & 223 & 639 & 334 & 394 & - & 12096 & - \\
\hline $\mathrm{Ga}$ & - & 377 & - & - & - & - & - & - & - & - & - \\
\hline $\mathrm{Ge}$ & - & 620 & - & - & - & - & 246 & - & - & - & - \\
\hline As & - & - & - & - & - & 442 & - & - & - & - & 442 \\
\hline $\mathrm{Se}$ & 696 & - & - & - & - & - & - & - & - & - & - \\
\hline $\mathrm{Br}$ & - & 764 & - & - & - & 1013 & - & - & - & - & - \\
\hline $\mathrm{Rb}$ & - & 1093 & - & 922 & - & 1114 & - & - & 766 & - & 1323 \\
\hline $\mathrm{Sr}$ & 1098 & 741 & - & - & - & - & 774 & - & 946 & - & - \\
\hline $\mathrm{Y}$ & - & 1208 & - & - & - & 800 & 1239 & - & 1176 & - & 1272 \\
\hline $\mathrm{Cd}$ & - & - & 380 & - & - & - & - & 806 & - & - & 638 \\
\hline $\mathrm{Sn}$ & - & 1690 & - & - & - & - & 961 & - & - & - & - \\
\hline $\mathrm{Sb}$ & - & - & - & - & - & 860 & - & - & - & - & 1164 \\
\hline I & - & - & 1116 & - & - & 773 & - & 1450 & - & - & - \\
\hline $\mathrm{Ba}$ & - & - & - & - & 1868 & - & - & - & - & 2173 & - \\
\hline W & - & - & - & - & - & - & 517 & - & - & - & - \\
\hline
\end{tabular}

As it can be seen on table 3 , the following 8 elements are constantly present in all 11 honey samples: $\mathrm{Al}, \mathrm{Si}, \mathrm{Cl}, \mathrm{K}, \mathrm{Ca}, \mathrm{Cr}, \mathrm{Fe}, \mathrm{Cu}$. The following elements are present in honey samples inconstantly: Co (in 10 samples) $\mathrm{Mg}, \mathrm{Zn}$ and $\mathrm{Ni}$ (in 9 samples) P (in 8 samples) Mn (in 7 samples).

Thus, in honey, stored during 1 year and in fresh one there was registered the constant presence of such elements as: $\mathrm{Si}, \mathrm{Cl}, \mathrm{K}, \mathrm{Ca}, \mathrm{Cr}, \mathrm{Fe}$. Whereas Ni was present in all honey samples, stored during 1 year, and $\mathrm{Cu}$ was revealed in all samples of fresh honey. The obtained results were compared with literary data, where peculiarities of the elemental composition of honey from different countries 
were indicated [10-13]. For example, such elements as $\mathrm{K}, \mathrm{Ca}$, $\mathrm{Na}$ and $\mathrm{Mg}$ prevailed in Chinese honey, in separate regions of Turkey $-\mathrm{K}, \mathrm{Na}$ and $\mathrm{Ca}$, in Brazil - $\mathrm{K}$ and $\mathrm{Ca}$. The Odessa region is typical by the content of $\mathrm{Cl}$ ions in air that influenced the content of this element in honey. The ratio of correspondent elements depends on soil, where bee plants grow and from the external environment, so it may be a marker parameter. The content of these elements is closely connected with honey authenticity and may serve a marker parameter, typical for polyfloral honey of the Odessa region.

Thus, if honey will be supplied to the international market from the Odessa region of Ukraine as a cleaner one, it must contain the greatest amount of three cited elements, determined by the most intensity of the radiological signal. If honey will be supplied from a more ecologically polluted region, for example, Kharkiv one - it undoubtedly has much $\mathrm{Cl}$ and the other marker elements. At the same time bee plants of the Odessa region are more biologically active (enzymes, vitamins), because this region has more number of sunny days and softer climate. So, honey has more healing biologically active substances.

\section{Conclusions}

As a result of this study, it has been established that honey samples from the Odessa region constantly contain the following elements: $\mathrm{Al}, \mathrm{Si}, \mathrm{Cl}, \mathrm{K}, \mathrm{Ca}, \mathrm{Cr}, \mathrm{Fe}, \mathrm{Cu}$ (in fresh honey) and $\mathrm{Si}, \mathrm{Cl}$, $\mathrm{K}, \mathrm{Ca}, \mathrm{Cr}, \mathrm{Fe}, \mathrm{Ni}$ (for honey samples, stored during 1 year).

The most intensity of x-ray signals was observed for such elements as $\mathrm{Cl}, \mathrm{K}, \mathrm{Ca}$. Honey, stored during 1 year had more intensity of spectral lines of $\mathrm{Cl}, \mathrm{K}$, Ca comparing with fresh honey, that is explained by its dehydration at storage and relatively higher density. At the same time it has been determined, that $\mathrm{K}$ is the first element by the intensity level of $\mathrm{x}$-ray signal, $\mathrm{Cl}$ - on the second place, then Ca.

Thus, at studying honey from the Odessa region by the energy-dispersive $\mathrm{x}$-ray fluorescent spectrometer, it has been established, that $\mathrm{Cl}, \mathrm{K}, \mathrm{Ca}$ are the most spread elements. These three elements generated the following values of X-ray signal: for fresh honey: $\mathrm{Cl}-27075-29429$; $\mathrm{K}$ - 47296-41546; Ca - 7572-6928; for honey, stored during 1 year: $\mathrm{Cl}-40383-37044$; $\mathrm{K}-$ 43589-42591; Ca - 15495-10006.

The presented results allow to define the geographic location of honey, and the described method may be used by specialists of laboratories that determine quality parameters of food products as an expressed method of the honey quality evaluation.

An advantage of this study is its easiness and speed of conduction; its results are evaluated by the intensity of x-ray signal in spectrograms, obtained by the energy-dispersive x-ray fluorescent spectrometer. The most signals in honey of the Odessa region must correspond to such three elements as $\mathrm{Cl}, \mathrm{K}, \mathrm{Ca}$. The obtained results will be useful for honey producers in the concrete Ukrainian region - namely in Odessa one. Using this method for determining marker parameters of the elemental composition of honey, fixed by us, it is possible to confirm the authenticity of honey from the Odessa region and to mark it correspondingly. In this connection Ukraine will receive the new brand product and a great possibility to realize it by more profitable prices at the international market. The results of these studies may serve as an idea for analogous studies and searchers for markers of honey by its elemental composition in other regions of Ukraine, for example, Transcarpathian one, where honey is also eco-safe and healing, and also for different regions of other countries.

Despite the fact that the offered method may be used in practice, it must be improved for the future to obtain quantity parameters of $\mathrm{Cl}, \mathrm{K}, \mathrm{Ca}$ in honey for more concretization of obtained data. The determination of $\mathrm{Cl}, \mathrm{K}, \mathrm{Ca}$ in honey by such indirect parameters as an X-ray signal intensity by the energy-dispersive $\mathrm{x}$-ray fluorescent spectrometer must be added by the method of recalculation and obtaining of quantity parameters that need additional studies. It is a field of further studies.

\section{References}

[1] García, N. L. (2018). The Current Situation on the International Honey Market. Bee World, 95 (3), 89-94. doi: https://doi.org/10.1080/0005772x.2018.1483814 
[2] Machado De-Melo, A. A., Almeida-Muradian, L. B. de, Sancho, M. T., Pascual-Maté, A. (2017). Composition and properties of Apis mellifera honey: A review. Journal of Apicultural Research, 57 (1), 5-37. doi: https://doi.org/10.1080/00218839.2017.1338444

[3] Serrano, S., Villarejo, M., Espejo, R., Jodral, M. (2004). Chemical and physical parameters of Andalusian honey: classification of Citrus and Eucalyptus honeys by discriminant analysis. Food Chemistry, 87 (4), 619-625. doi: https://doi.org/10.1016/j.foodchem.2004.01.031

[4] Mulugeta, E. (2017). Physicochemical Characterization and Pesticide Residue Analysis of Honey Produced in West Shewa Zone, Oromia Region, Ethiopia. American Journal of Applied Chemistry, 5 (6), 101-109. doi: https://doi.org/10.11648/j.ajac.20170506.13

[5] Lenhardt, L., Zeković, I., Dramićanin, T., Dramićanin, M. D., Bro, R. (2014). Determination of the Botanical Origin of Honey by Front-Face Synchronous Fluorescence Spectroscopy. Applied Spectroscopy, 68 (5), 557-563. doi: https://doi.org/10.1366/13-07325

[6] Thrasyvoulou, A., Tananaki, C., Goras, G., Karazafiris, E., Dimou, M., Liolios, V. et. al. (2018). Legislation of honey criteria and standards. Journal of Apicultural Research, 57 (1), 88-96. doi: https://doi.org/ 10.1080/00218839.2017.1411181

[7] Uršulin-Trstenjak, N., Levanić, D., Šušnić, S., Lasić, D., Šušnić, V. (2015). Determination of geographical origin of black locust honey of five Croatian regions by applying the PCA method. Journal of Hygienic Engineering and Design, 13, 68-74.

[8] Uršulin-Trstenjak, N., Levanić, D., Primorac, L., Bošnir, J., Vahčić, N., Šarić, G. (2016). Mineral profile of Croatian honey and differences due to its geographical origin. Czech Journal of Food Sciences, 33 (2), 156-164. doi: https://doi.org/10.17221/502/2014-cjfs

[9] Silva, L. R., Sousa, A., Taveira, M. (2017). Characterization of Portuguese honey from Castelo Branco region according to their pollen spectrum, physicochemical characteristics and mineral contents. Journal of Food Science and Technology, 54 (8), 2551-2561. doi: https://doi.org/10.1007/s13197-017-2700-y

[10] Chen, H., Fan, C. L., Chang, Q. Y., Pang, G. F., Cao, Y. F., Jin, L. H., Hu, X. Y. (2015). Application of ICP-MS method in the determination of mineral elements in vitex honey for the classification of their geographical origins with chemometric approach. Spectroscopy and spectral analysis, 35 (1), 212-216.

[11] Ribeiro, R. de O. R., Mársico, E. T., de Jesus, E. F. O., da Silva Carneiro, C., Júnior, C. A. C., de Almeida, E., Filho, V. F. do N. (2014). Determination of Trace Elements in Honey from Different Regions in Rio de Janeiro State (Brazil) by Total Reflection X-Ray Fluorescence. Journal of Food Science, 79 (4), T738-T742. doi: https://doi.org/10.1111/1750-3841.12363

[12] Zhou, J., Suo, Z., Zhao, P., Cheng, N., Gao, H., Zhao, J., Cao, W. (2013). Jujube Honey from China: Physicochemical Characteristics and Mineral Contents. Journal of Food Science, 78 (3), C387-C394. doi: https://doi.org/10.1111/1750-3841.12049

[13] Kılıç Altun, S., Dinç, H., Paksoy, N., Temamoğulları, F. K., Savrunlu, M. (2017). Analyses of Mineral Content and Heavy Metal of Honey Samples from South and East Region of Turkey by Using ICP-MS. International Journal of Analytical Chemistry, 2017, 1-6. doi: https:/doi.org/10.1155/2017/6391454

[14] Zalog zdorov'ya. Ekologicheskiy reyting oblastey Ukrainy. Available at: https://greenfund.com.ua/ 2019/01/21/zalog-zdorovya-ekologycheskyj-rejtyng-oblastej-ukrayny

[15] Borovikov, V. (2003). Statistica. Iskusstvo analiza dannyh na komp'yutere. Sankt-Peterburg: Piter, 688 . 